\title{
The biochemistry of blood coagulation
}

Citation for published version (APA):

Hemker, H. C. (1982). The biochemistry of blood coagulation. In C. Smit Sibinga, P. C. Das, \& J. J. van Loghem (Eds.), Bloodtransfusion and Problems of Bleeding (1 ed., pp. 3-14). Springer. Developments in hematology and immunology Vol. 5 https://doi.org/10.1007/978-94-009-7692-4_1

Document status and date:

Published: 01/01/1982

DOI:

10.1007/978-94-009-7692-4_1

Document Version:

Publisher's PDF, also known as Version of record

\section{Please check the document version of this publication:}

- A submitted manuscript is the version of the article upon submission and before peer-review. There can be important differences between the submitted version and the official published version of record.

People interested in the research are advised to contact the author for the final version of the publication, or visit the DOI to the publisher's website.

- The final author version and the galley proof are versions of the publication after peer review.

- The final published version features the final layout of the paper including the volume, issue and page numbers.

Link to publication

\footnotetext{
General rights rights.

- You may freely distribute the URL identifying the publication in the public portal. please follow below link for the End User Agreement:

www.umlib.nl/taverne-license

Take down policy

If you believe that this document breaches copyright please contact us at:

repository@maastrichtuniversity.nl

providing details and we will investigate your claim.
}

Copyright and moral rights for the publications made accessible in the public portal are retained by the authors and/or other copyright owners and it is a condition of accessing publications that users recognise and abide by the legal requirements associated with these

- Users may download and print one copy of any publication from the public portal for the purpose of private study or research.

- You may not further distribute the material or use it for any profit-making activity or commercial gain

If the publication is distributed under the terms of Article $25 \mathrm{fa}$ of the Dutch Copyright Act, indicated by the "Taverne" license above, 


\section{THE BIOCHEMISTRY OF BLOOD COAGULATION}

:.C. Hemker

\section{I:TRODUCTION}

Thrombin is the central enzyme in hemostasis and triomizosis. Ihe study of its generation has been promptes $=\because$ the many diseases in which hemostasis and trombosis $=-j y$ a rol The bleeding disorders like hemophilia $\lambda$ are ozvious but rare examples. Wuch more common is the other extrene: the

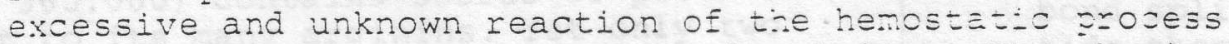
known as thrombosis and its sequel embolism. Trromiosis on basis of atherosclerosis and thrombosis in =ne veins are very important pathological processes. Evisexa is raziaiy

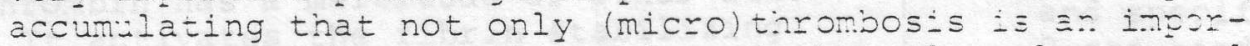

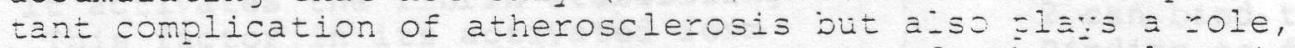
maybe even the main role, in the genesis oj atrezosciezosis. Thrombosis in one form or another may therezore je consicered to be a key event in well ovez hal o o $a_{-1}$ a the western society, including nell-kncin. dise三ses as coronary infarction, stroke, circulaticn aiszuriardes in. the legs, kidney disease etc. Thromin generazion. zherejorきis a suitable subject of research in a icoremis:of a medical faculty. On the other hand it sicus so many novel features not recognized in erzmolog: $\because n=i-$ n. it cannot fail to interest ever the most basic: $\because$ inter biochemist.

Since the midale of the last certury, trromin is knowr. to clot blood, to cause a fibrinogen solution =0 turn into a jelly-like mass. This phenomenon is most ingressing :n vitro, but probably is of minor imsortance in cencstasis and tirrombosis. Since the early sixties, i= has iseer. recocnized that thrombocytes (blood platelets) pla

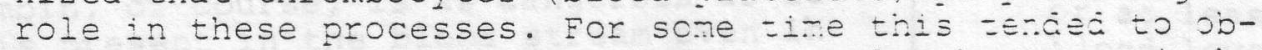
scure the role of thrombin. More recently, horerer, it be-

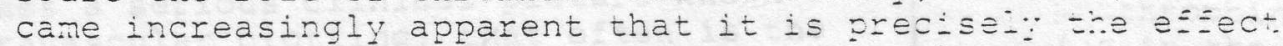

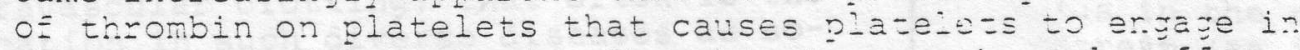
thrombosis and hemostasis. Thrombir is not tre cni tor for these cells. Prostaglariins, ADP, sez=:0nin ezz.

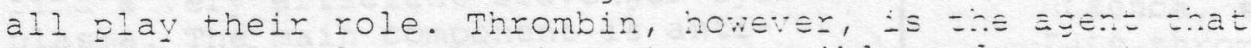
makes the platelet reactions irreversible anj $=0 z \in n=$ rき-

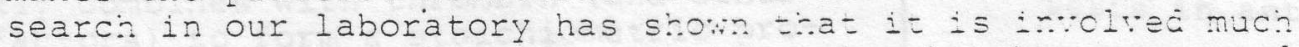

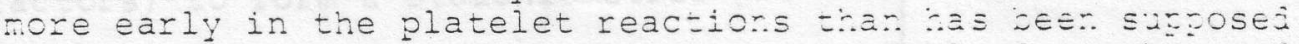
before. Anyhow, the view that clotzing $0 \equiv 210 z=$ is cioserved 
in venous thrombi only and that therefore thrombin plays a role in venous thrombosis only, although still widely supportej among practitioners and pathologists, is no longer tenable.

\section{WHAT IS THRO:IBIN?}

Thrombin is a proteolytic enzyme of the serine protease zamily. It is not unlike trypsin, in that it is specific Eor bonas next =o arginin. Its main or B-chain containing the active serine shows extensive homologies with trypsin, chymotryosir. anc elastase as well as with the other proteases $0=$ bloca coagulation that we will discuss presently. Ihe 3 -chain contains aminoacids (in bovine material) and is S-S linke $=0$ the A-chain, 58 residues in length. The orimary structure of both chains has been solved in the laborazcryc c Nagnusson.

The furction $0=$ the - - chain is as yet obscure. It can be safely guessed that it will play a role in the striking specificity oz zis enzyme. This specificity is already illustra=ea by its action on fibrinogen. The large fibrinogen nolevulé $\times$. 360.000 ) contains scores of potential vinerable bords next to its many arginins. Yet only tiwo o: these are sミ-it by thrombin. This generates the fibrin monomer that sponzaneously polymerizes and thus causes 'clotting' ger se. Thrombin has a multitude of other functions ir. hetostasis. It activates the fibrin stabilizing factor (factor YIII). This factor in its activated form links lysin resiaues to glutamic acid residues in adjacent units of the po-ymer and thus covalently links the clot. It also activates procoagulant factors (factors $V$ and VIII) and this is coupled in a positive feedback system to its own generation. The way in which these factors act will be discussed below.

Thrombin also partakes in a negative feedback because it splits its proenzyme (prothrombin = factor II) into a product that is less readily activated than intact prothrombin. Thirdly, and perhaps most important, thrombin acts on thromiccytes. It causes them to aggregate a basic reaction of these cells in plugging a hole in a:blood vessel as well as the first recognizable event in thrombosis and probabl ir. the generation of atherosclerosis. It also causes them to nake available the phospholipids that are recessary for the clotting process: another form of positive feecibazk. Itrombin, of course, is as dangerous as it is use $\because 1$. When. it is present in the blood stream even in iny amounts as aissemin...tec intravascular clotting, that often is the inal letnal ccmplication in such diverse diseases as solutic placen=三三, traumatic brain damage or leukemia. One

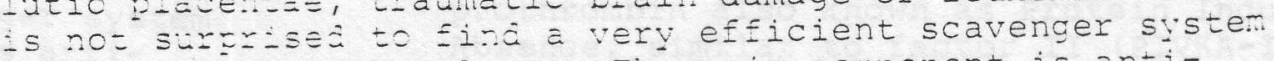
for tiromin in the plasma. The main component is anti-

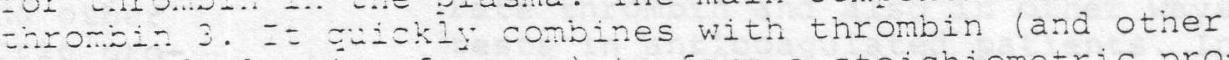

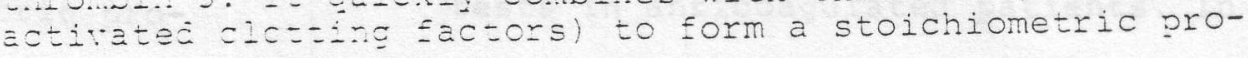


duct with no enzymatic activity. An important recent event in blood coagulation research is the development of ciromogenic substrates. These are tri- or tetrapeptides linkea to a p-nitroanilide residue. They can be designed to se relatively specific for thrombin or other clotting esterases and thus make it feasible to estimate the enzymes spectrophotometric assay. This circumvents much technical problems adherent to the study of the coagulation system by measuring clotting times.

\section{WHAT IS PROTHROMBIN? HOW IS IT ACTIVATED? ROLE OF VITAMIN K}

prothrombin is the zymogen for thrombin. It is a single chain molecule of amino acid residues. The molecular weight is 72,000 . It contains both the $A-$ and the B-chain of thrombin but these only account for slightly more than half of the molecule.

In other words, there is an unusually large activation peptide. In order to generate the two chain trombin molecule it has to be split in two sites. The primary structure of prothrombin is known as well as the probable order o bond splitting during activation. In the activation peptide there is a site vulnerable to the action of thrombin. This splits the activation peptide in two parts, called fragment 1 and fragment 2. These regions have differer. and specific functions in the activation process. Fragment 2 can bind to factor $V$. Fragment 1 binds to phospholipia. Binding to factor $V$ and phospholipid of the prothrombin molecule greatly enhances its liability of being actirated as we will see later. Of particular interest is the way in which fragment 1 , the $\mathrm{N}$-terminal end of prothrombin, binds to phospholipid. For this function it is necessary that ten glutamic acid residues in this part of the molecule are converted into $\gamma$-carboxyglutamic acids. $\because-$ carboxyglutamic acid (gla) residues are formed by carboxylation of glutamic acid residues in the polypeptide that but for these carboxylations is identical to prothromini. This carboxylation is an unusual reaction in that it requires reduced vitamin $\mathrm{K}, \mathrm{O}_{2}$ and $\mathrm{CO}_{2}$ but no biotin or ATP. Recently, the liver enzyme responsible for this reaction has been isolated in our laboratory. If by a lack of vitamin $K$ or by the administration of vitamin $K$ antagonises (the so-called oral anticoagulants, mostly coumarin derivatives) the carboxylation step cannot be carried out, no or at least not enough prothrombin is synthesized and tiee blood level drops. The precursor, i.e. the uncarboxylated prothrombin precursor either remains in the liver cell (as in the rat and chicken) or does not reach the blood stream (as in men and cows). This circulating descarboxyprothrombin also known as protein Induced by Vitamin $K$ Absence, similar to factor II (PIVKA-II), may slowly generate thrombin and also in other ways disturb coagulation. tests in anticoagulated patients. In fact, it was by these 
ezfects that it was first recognized. It is one of the factors that makes the control of oral anticoagulant treatment a difficult task and thus contributes to the occasioral failure of this useful therapy. Apart from this, PIVKAI can be isolated from plasma and because it is completely identical to prothrombin but for the capability to bind to chospholipids, it is a perfect model to study the lipia binding of this clotting factor. It may be mentioned already now that the other vitamin $K$ dependent clotting factors (i.e. factors VII, IX and $X$ ) also show gla residues, that aiso serve to bind them to phospholipid surfaces. When no vitamin $K$ is present (c.q. When its action is blockea) analogs of these factors, called PIVKA-VII, PIVKA$I X$ and PIVKA-X, occur in the blood stream.

The bonds that need to be split in prothrombin in order to liberate thrombin are clipped by proteolytic enzymes. Inis can be cone by trypsin, by certain snake venoms or iz activated factor $x$. These reactions occur in free solution but are not very efficient. Under physiological circumstances a more sophisticated biochemical mechanism is operative.

\section{PROTHROMBINASE}

The normal physiological activator of prothrombin consists of Eactor $\mathrm{X}_{a}$ bound to a phospholipid surface next to a molecule 0 factor $V_{a}$. Factor $X_{a}$ is the activated form of Eactor $\mathrm{X}$, one of the vitamin $\mathrm{K}$ dependent coagulation factors. This factor occurs in the blood in a two-chain form. The heavy chain ( $\mathrm{N}$ 4 4,000) contains the active serine and is $\mathrm{S}-\mathrm{S}$ bound to the light chain (MW 17,000) that contains 12 gla resicues in its $N$-terminal part. Upon activation, the mechanism of glycopeptides is removed from the N-terminal part of the heavy chain. Unlike thrombin, this activated enzyme in this case does possess a gla containing region, and it is via this region that it can bind to phospholipid. Extensive comparisons carried out in our lab between factor $x$ and PIVKA-X, the decarboxy form of the enzyme found in vitamin $K$ deficiency, show that PIVKA-X can be activated like factor $X$ and then acquires properties inaistinguishable from factor $X_{a}$ when reactions are studied that take place in free solution. When the reaction takes place at an interface, the properties are very cifferent indeed.

Eactcr $V_{a}$ is a $100,000 \mathrm{MW}$ two-chain protein that arises from a $360,000 \mathrm{MW}$ single-chain precursor in an as yet not completely clear way. The activation under physiological circumstances is carried out by thrombin.

It shoula be mentioned that no enzymatic activity of Eactor $V_{a}$ is known. Activation here does not mean a proenzyme-enzyme corversion, as it does with all other coagilation factors except Eactor VIII. Early experiments shoned that factor $x_{a}$ alone is capable of splitting prothrombir but that its catalytic action is enhanced up to 
several thousand fold by the addition of phospholipids and Eactor $V_{a}$ that both are inactive as such.

Early kinetic experiments showed that protiromicinase is formed by independent reversible adsorption o $=$ =he factors $V_{a}$ and $X_{a}$ on the phospholipid surzace.

$I=$ thus appears that an interesting question in general enzymology arises. Why is it that an enzyme (Eactor $x_{\equiv}$ ) is much more potent when it acts in concerted action $\because i t h$ an accessory factor, also called paraenzyme ( actor $V_{\equiv}$ ) adsorbed at an interface? The question may be of much more general importance than for the activation of prothrombin alone. Not only does a similar situation occur in the acivivion of factor $x$, but also the same configuration is encountered several times in the complement s:sten. I: also can be recognized in oxidative phosphorylation and it might indeed be a feature of many reactions occurring at membrane-solution interfaces.

\section{THE REACTIONS LEADING TO THE ACTIVATION OE EACTOR $X$}

The Eactor $\mathrm{X}$ activated enzyme is the vitamin $\mathrm{K}$ depenajent, hence gla-containing, hence lipid binding factor IXa. Precise-y like factor $X_{a}$ it needs for its full activit: sorption onto a phospholipid surface and a para-enzyne, in this case factor VIII. Factor VIII remains a somenihat enigmatil protein and I will not discuss it to an extent here. It is sufficient to say that it probably is a polymer of two different proteins, one of which is active in coazulation. Iike factor $V$ it is activated by thromin.

Factor $I X_{a}$ in its turn arises from factor IX in a reaction catalyzed by factor XIa. The mechanism o $\mathrm{XI}_{a}$. Tomation of factor XIa has been unraveled in the last ze: years. It is a direct consequence of contact of bloca aith regatively charged Nettable surfaces.

In the presence of such a surface, factor $\because I I$ asscrbs from the plasma and in adsorbing undergoes a conforma:ional change that makes it a suitable substrate for kaIikrein. Kallikrein, however, does not act as such. In plasma it is bound to high molecular weight kinirogen ( $:$...ik). Via HMTK that contains a domain of about 120 resiaues, $30 \%$ of which are histidines, and that hence bears a strorgly positive charge, kallikrein binas to the negazive surkace, hext to factor XII and is capable o J activating jactor XII. On the other hand, factor XII can activate pre:ilikrein when it adsorbs, also via HMW.

This mutual activation leaves us with the guestion of how the process starts. If both factor XII a.: orekailikrein were absolutely inactive pro-enzymes, the reaction could not be triggered without the help of another erzyme. it the moment we think that the proenzymes are not ccmpletely inactive, that some interaction is always possidie but that this is easily repressed by the antiprotease abundant in plasma.

By adsorption to a negative surface two phenomena occur 
simuitaneousiy:

a. Zactor XII becomes a better substrate

b. the concentration of the reactants near the surface is enhanced.

This the factors engage in a strongly non-linear interaction that breaks through the protective action of the antiproteases.

Factor XII activates factor XI that like (pre)kallikrein is bound to the negatively charged surface by HMWK. Factor XIa tinen activates factor IX. The pathway here describec is called the intrinsic pathway because no material aiten to the blood plays a role in it.

There is another pathway. A lipoprotein present in almost all cells and called tissue thromboplastin can inter$a c=$ with a vitamin $\mathrm{K}$ dependent plasma protein factor VII tc form a complex in all probability completely aralogous to the prothromin and intrinsic factor X activating comp-exes that can activate factor $X$. Factor $X_{a}$ in its turn can activate zactor VII and between these two proenzymes a situation o Feciprocal activation may exist not unlike tiee situation between factor XII and factor XI described azove. Oniy here the reaction occurs at a phospholipia scirable incerface.

It becomes more and more clear that the factor VII dependent pativiay is not completely independent of the intrinsic pathway. It has been known for a long time aná has been again found with modern methods that factor VII acts upon factor IX. In fact under conditions tha only a action of factor VII upon factor X is markediy enhanced $b \because$ the presence of the factors VIII and IX, but indepenaen $=$ of the contact factors.

Eactors VIII and IX thus seem to act as an accessory factor $X_{i}$ activator that can be triggered by factor VII and tissue thromboplastin.

\section{THE FUNCTION OE COMPLEX ENZYMES}

The data in the literature only state that phospholipids and factor $V_{a}$, each alone enhance the activity of factor $x_{a}$ as a prothrombin activator and that, when both are present together their action is markedly increased. We tried to find out what the mechanism behind this phenomenon is.

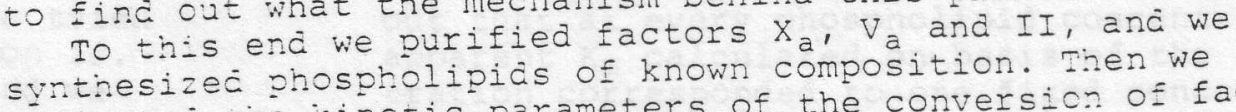
estimated the kinetic parameters of the conversion of facoor II by the different possible activating enzymes, i.e. zactor $x_{a}$, factor $x_{a}$ - phospholipid, factor $x_{a}$ - factor ${ }^{\prime}{ }^{\prime}$ zactor $\mathrm{X}_{\text {a }}$ - factor $\mathrm{V}_{\mathrm{a}}$ - phospholipia. The rate o formailon o thrombin at different prothrombin concenzrations ras measurea by subsampling from the incubation mixture into a cuvette containing S 2238, a chromogenic substrate for thromith and assessing the amount of thrombin from zhe rate oj color production observed. In this way Iine- 
weaver-Burk plots of each of the enzymes could be obtained. It was seen that - but for a rare exception to be discussed later - straight Lineweaver-Burk plots were obtained.

We found that phospholipids decrease the $\mathrm{K}_{\mathrm{m}}$ by about 1000-fold and that factor $V$ increases $V_{\max }$ by about the same factor.

It is obvious that the overall rate enhancement attained by the combination of these effects can be enormous. The concentration of prothrombin in plasma is about $2 \mu \mathrm{M}$ and it is seen that addition of phospholipid moves the $K_{m}$ from above this value to well below it. Experiments on the factor $x$ activating complex showed that completely comparable kinetics were observed here with factor. $X$ in the role of substrate and factors $I_{a}$ and VIII acting as enzyme and paraenzyme. The effects of the phospholipids and factor $V$ are clearly different and the next task would be to seek a mechanistic explanation for the observed facts.

\section{THE PHOSPHOLIPIDS}

Already in 1967, we had found that excess phospholipid innibits the formation of prothrombinase and we explained this phenomenon by assuming that the reaction of prothrombinase with prothrombin takes place in the two-dimensional compartment formed by the phosprolipid-water interface. Addition of an excess of phospholipid increases this interface and dilutes the protein components in it. If this is the right explanation then the kinetic constants observed in bulk solution are only apparent constants and should be recalculated so as to represent the situation at the surface. For this we set out to determine the apparent $\mathrm{K}_{\mathrm{m}}$ and $\mathrm{V}_{\mathrm{max}}$ at a range of phospholipid concentrations.

If appeared that $K_{m}$ shows a clear variation with the phospholipid concentration. From the literature the dissociation constant and the number of binding sites of prothrombin for the type of phospholipid we used could be obtained. With the aid of this constant the concentration of prothrombin at the surface could be calculated. It turned out that at every phospholipid concentration the variable apparent $\mathrm{K}_{\mathrm{m}}$ calculated on basis of the bulk phase concentration correspondea to one fixed concentration of adsorbed prothrombin. The same phenomenon could be still more elegantly demonstrated with the factor $\mathrm{X}$ converting enzyme. Here we found a method to estimate the dissociation constant and the number of sites for factor $X$ onto the phospholipid on the same day and in the same preparations as used for determination of the kinetic constants. This method is based on the fact that a proteolytic protein from the venom of Russelis Viper (called in short RVV-X) activates factor $x$ in free solution but does not act on the adsorbed enzyme. From the velocity of factor $X$ formation 

free factor $X$ thus be immediately assessed. When this is done in a series of concentrations a scatchara plot can be constructed that yields both the dissociation constant and the number of binding sites for factor $X$ on phospholipid.

Also in this case it became clear that the reaction shows its half maximal reaction velocity at a fixed number 0 I substrate molecules adsorbed per amount of lipia. f.part fron the substrate also the enzyme has to adsorb on the phospholipid. Under the conditions of our experiments ith prothrombinase we saw that $V_{\max }$ increased slightIY with the concentration of phospholipid. As $v_{\max }$ is proportiorec to the enzyme concentration this was thought to reflez= a more complete binding of the enzyme at higher phospholipid concentrations. The fact that this phenomecentrajion can be explained from the higher affinity of centrajion can be explained from
the en:yme (Eactor $x_{a}$ ) for the surface and from the fact
that only small amounts of factor $x_{a}$ are present $i . e$. the amount of Iipic present is in excess over the amount of factor $x_{a}$ and therefore the binding of factor $\mathrm{X}_{a}$ is favoré.

These results all point in the direction that the reacsorbec substrate. The
mensicnal reaction vessel' in which the molecules meet.
Why should the reaction be favored by this arrangement. on eirst sight it is clear that the concentration at the surface is higher but a second thought learns that this as such will not increase the interaction velocity. For the nclecules to interact they have to meet and it is not clear that adsorbed molecules are free to meet. Two argumenzs can be brought forward that favor the model proposed. The first is a theoretical one. From various types of experiments an estimate can be made of the lateral mobilit $\because$ of proteins adsorbed onto phospholipids. One can calcuiate the collision frequency and compare it to that in free solution. It turns out that the collision frequency of adsorbed protein may be easily some. 100 to 1000 quency of adsorbed protein may be easily some. The second
times higher than that in the free solution. The
argument in fact shows that an experimental change in diffusic. coefficient does increase the reaction rate. We coula show that the procoagulant activity of synthetic phoszholipias sharply increases at the transition temthe phospholipias. As it can be assumed that the -atera- aizfusion coefficient increases sharply above the zransizion temperature, this car be accepted as evidence in favor of our model. Apart from increasea collsion Erequency adsorption at mechanisms. In free solution colliaing ably by two other mechanisme first contact at random places of nolezules will make treir surkaces. When adsorbed they are orlented because
one $\equiv$ pecific part of the molecules - the gla containing 
:-terminal end - interacts with tre phosphoiloias. Co:liding adsorbed molecules therefore hill make Iirs= cznlact at restricted places on their sur zace and jis noiscoules may be so constructed thaz tris causes m=r@ =01.sions to result in interaction.

Thirdly, the adsorption may cause conformazicn三l changes in the proteins and thus make them nore reactive. Fisis cossibility is as difficult to rezu=e as it is =0 pro:e and is only interesting when other explanations jail. In the contact activation mechanism it nay be the oniy remaining possibility. It is as yet not absolutely necessary to postulate it in this case. Vie concluded tiat adsorption onto phospholipid increases the number of fa:orable collisions between the molecules, therefore acts as if increasing the concentration of sibstrate ard thus causes a decrease of $K_{m}$.

\section{THE PARAENZYMES}

The activation of factor $X$ involves the splitzirg o peptide bond only. The kat of this reaction is increasea by factor VIII, the accessory protein in this case. We inerefore have to consider an inziuence o this prove:n on the reaction mechanism of the splitting.

special attention should be pais =0 the possibilit: of tie occurrence of noncovalent complexes. The increjse cf ary forward rate constant in this mechanis... $\because i \mathrm{i} r \equiv-$ sult in an increase of the observes kcat. Nith sma-l amide substrates acylation is the raze-linjtiry ste:. The rates that are observed with small sibstrazes are explained jy a $k_{c a}=$ of 10-100. Without factor VIII the kcalo actiration is much lower $\left(10^{-4}\right)$. W- factor VIII kcal is restored to about the level seen with small subs=razej $(\sim 2)$. This suggests that rather thar accelerating the catalytic mechanism per se, factor VIII brings about conciticns that make the enzyme as efjective with iarge $\equiv u b-$ strates as with small ones. This suggests that tie mecharism of bond breaking as such is not involved, becaus this is not different in large and in small suiostrates. Rather would one expect an effect on interactions tia are known to be different for these wo types of sibs wates, i.e. the noncovalent interactions. Ne .ill see trat in the case of prothrombin more arguments can be jrought forward for tinis view.

The case of prothrombin is more complicatec though. Here two peptide bonds have to be szitt in the substrate. The minimal possible reaction scheme therefore is:

It appears from an analysis of the reaction projucts obtained with different forms of profirombinas a =ia in the absence of factor $V, P_{2}+F$ is tise main $r \in \equiv c=i o n$ Eno-

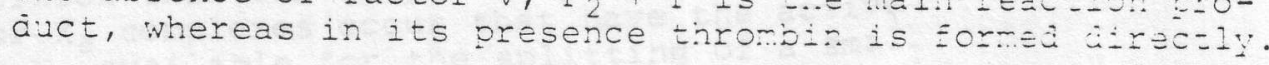


So in. :ie absence of factor $V, P_{2}$ dissociates readily from - $\mathrm{xe}$ exzye jut in its presence not. In order to discuss zhis fhenomenon we will employ a simplified form of the reac=ion. screme:

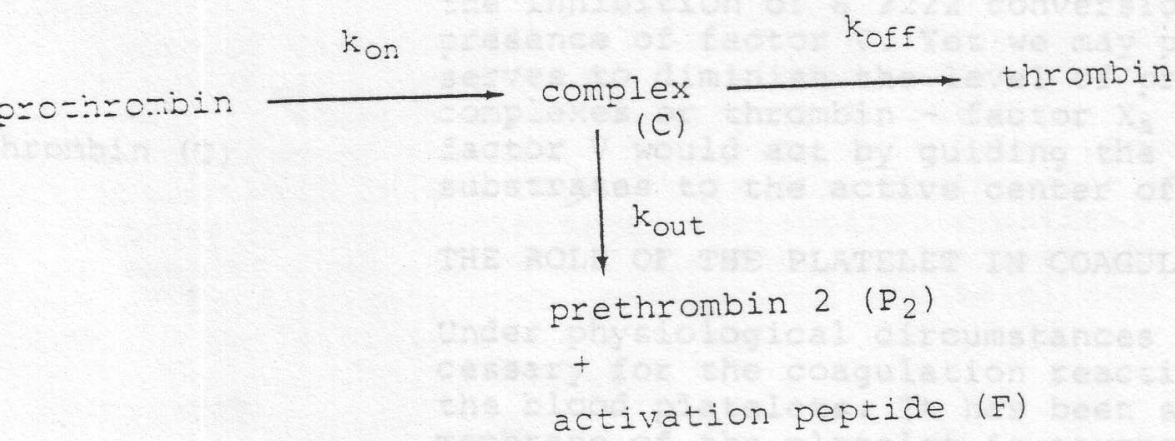

Eaztur $V$ car prevent the production of $P_{2}$ in one of two $\therefore \cdots$ s. Eizher kou is decreased or the steady state concen-

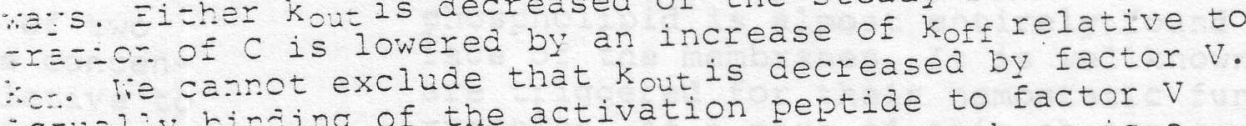
anuliy binaing of the activation peptide to factor $V$ cas deen observed and it is also known that there is a $r e-a=i v e l y$ light noncovalent binding between $F$ and $P_{2}$. It car. be easily argued, however, that a decrease of kout sa: nct be the only mechanism involved. In the first place

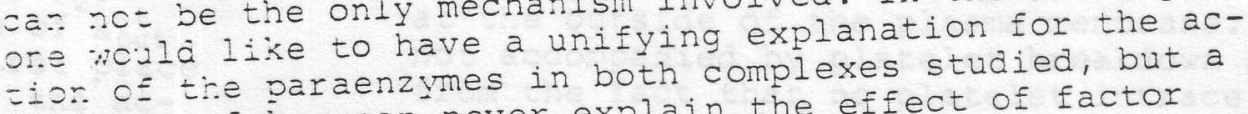
aecrease of kcat can never explain the effect of factor VIII on factor $x$ activation as only one bond splitting is involved there. In the second place $k_{c a t}$ of thrombin fornation in the presence of factor $V$ is about $50 \mathrm{~s}^{-1}$. This mears that both kon and kout should be at least $50 \mathrm{~s}^{-1}$. The rate of $\mathrm{P}_{2}$ formation in the absence of factor $\mathrm{V}$ was estimated by us to be $0.5 \mathrm{~s}^{-1}$ and the $\mathrm{k}_{\text {cat }}$ of thrombin formation was $0.05 \mathrm{~s}^{-1}$ under these circumstances. This is incompatible with forward rate constants of $50 \mathrm{~s}^{-1}$ or more. $s=$ one or both of the kinetic constants kon and koff have = $=$ increased by factor $V$.

$\therefore$ interesting observation is that although the action c Eactor $X$ a on its natural substrate prothrombin is in$\therefore i=t e c \quad i$ the presence of a competing small substrate $\equiv 2238)$, the action of factor $X_{a}$ on the small substrate - $=$ nct irinibited by the presence of prothrombin. Even $\therefore \in$ prozhrombin is present at concentrations of about $K_{r}$ $\equiv=$ ina cne would expect that about $50 \%$ inhibitor would azour. Ir. our opinion this can only be explainea if proaromin - Eactor $\mathrm{X}_{\text {a }}$ complexes occur that have the active

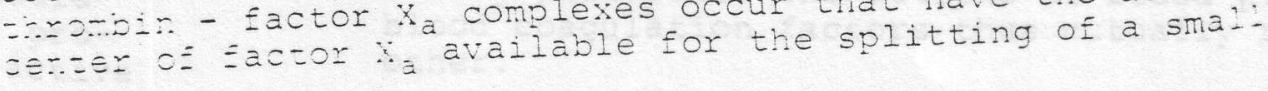


suissuate. If this is true, ther factor $\forall$ would act iy inminishing the amount of that type of complezes. Unforzunazely, technical difficulties prevent to investigate tre inhibition of S 2222 conversion by prothrombin in the presence of factor $V$. Yet we may postulate that factor $V$ serves to diminish the level of prothrombin - factor $\mathrm{X}$ complexes or thrombin - factor $x_{a}$ complexes. That is, zactor $V$ would act by guiding the large molecular weight substrates to the active center of the enzymes.

\section{THE ROLE OF THE PLATELET IN COAGULATION}

Under physiological circumstances the phospholipids necessary for the coagulation reackions are provided by the blood platelets. It has beer shown that the plasma membrane of the platelet is asymmetrical and that the chospholipid composition of the outside has no significart procoagulant properties whereas those at the inside have. Especially phosphatidyl serine (DS) is essential in proviaing the negative charge that is a prerequisite for binding of the $\vec{K}$ dependent clotting factors. This phospholipid is almost entirely jound at the inner surEace of the membranes. It is wellknown that platelets that are triggered for their hemostatic function show a release reaction. As a part of this phenomenon factor $V$ a is transferred from storage vesicles insiae the platelet to the outside. Ve could show that if piatelets are triggered by thrombin and collagen, procoajulant phospholipids appear at the outside of the plasma memirane. This phenomenon is not accompanied by platelet breaiajown as can be judged from the fact that no platelet intraceliular enzymes are released. On the other hand the material stored in the platelet granules (serotonin, factor V) is released. The procoagulant phospholipids remain an integral part of the platelet and, for more than $90 \%$ can be spun down with the platelet. We hypothesize that parts of the plasma membrane of the platelet turn inside out (flip-flop) so as to present their procoagulant inner surface when they are triggered. At the same time factor $V_{a}$ becomes available from the inside of the platelets. This explains the presence of highly specific factor $x_{a}$ biniing sites at the surface of activated platelets. The factor $X_{a}$ at the surface of a platelet is immune to activation by antithrombin 3 . The platelet reaction therefore provides a rich source of prothrominase activity. Also because platelets active in hemostasis stick to each other and to subendothelial structures, they create a sponge-like structure in the crevices of which flow will not wash away the thrombin formed. Thrombin again will induce release and flip-flop in neighboring platelets. The actions of biocd platelets and the blood coagulation factors thus mutually reinforce each

other. 
Erom the bicchemical point of view the blood coagulation mechanism offers the possibility of studying reactions ax: joes cover patterns that are not easily found elsewher .

Years of careful clinical observation have helped to so:- out those illnesses that, as experiments of nature, can help in solving these questions. On the other hand, in:estigation of the basic phenomena underlying thrombin fcrmation will in the end help in interfering with the processes of atherosclerosis, thrombosis, embolism, inträascular coagulation and bleeding tendencies, that toget:er form largely more than half of the total death toi: in our society at this moment.

\section{REEERENCES}

In. Hew cj the general nature of this overview further studies of the lizerature are best carried out on the hand of specialized review arこえこles.

1. ت̈aker, Z.C.: Capita Selecta: Vorming en functies van thrombine. $\because \equiv \bar{a}$. Iijaschr. v. Geneesk., 126:198,1982.

2. Nietich, J.P., Majerus, P.W. Properties of the factor Xa binaing site on human platelets. J.biol.Chem. 253:6908, 1978.

3. S.ttie, J.k. Jackson, C.M. Protinrombin structure activation ana z-osyntresis. Physio1. Rev. 57:1. 1977.

4. Z:aal, R.F.A.: Biochim.bicphys.Acta 515:163, 1978.

5. ZNaal, R.F.A., Hemker, H.C.: Blood cell membranes ana haemostasis. Kaemostasis, 11:12,1982. 